\title{
LEX ORANDI - FONTE DA ESPIRITUALIDADE CRISTÃ: ASPECTOS DE TEOLOGIA LITÚRGICO-ESPIRITUAL
}

\section{Lex orandi - Source of Christian Spirituality: aspects of Liturgical and Spiritual Theology}

Vanderson de Sousa Silva*

\section{RESUMO}

O presente artigo intenta perquerir a temática da Espiritualidade Cristã que encontra na Lex orandi sua fonte mais genuína. A questão central é esta: a liturgia é a espiritualidade da Igreja, como assevera Neunheuser, assim, nosso estudo gravita em torno da Liturgia como locus privilegiado da Espiritualidade Eclesial. Para isso, serão perqueridos aspectos lexicais, históricos e teológicos do binômio espiritualidade-liturgia.

Palavras-chave: Espiritualidade. Liturgia. Lex orandi. Espiritualidade Eclesial.

\section{ABSTRACT}

This article attempts to research the topic of Christian Spirituality that finds its source in the Lex orandi more genuine. The central question is this: the Sacred Liturgy is the spirituality of the Church as Neunheuser asserts, therefore, our study revolves around the liturgy as the privileged locus of Ecclesial Spirituality. To do so, runs will lexical aspects, historical and Theological-Liturgical Spirituality of the binomial.

Keywords: Spirituality. Liturgy. Lex orandi. Ecclesial Spirituality.

* Mestrando em Teologia Sistemático-Pastoral na Pontifícia Universidade Católica do Rio de Janeiro, PUC-RJ, graduado em filosofia, pedagogia e ciências sociais. E-mail: <semvanderson@hotmail.com>.

\begin{tabular}{|l|l|l|l|l|l|}
\hline Teocomunicação & Porto Alegre & v. 44 & n. 3 & p. 354-380 & set.-dez. 2014 \\
\hline
\end{tabular}




\section{Introdução}

Da Liturgia, portanto, mas da Eucaristia principalmente, como de uma fonte, provém a graça para nós e com maior eficácia é obtida a santificação dos homens em Cristo e a glorificação de Deus, para a qual, como a seu fim, tendem todas as demais obras da Igreja. ${ }^{1}$

Karl Rahner afirmou que o cristão do século XXI ou será místico ou não será cristão, acrescentando que não se entenda por mística os fenômenos parapsicológicos raros, mas uma experiência de Deus autêntica, que brota do interior da existência ${ }^{2}$ assegurando o específico da mística cristã que é experiência do Deus Trinitário, revelado na pessoa de Jesus de Nazaré e pela epíclise do Espírito.

Nosso trabalho intenta, pois, perquerir a temática da espiritualidade, delimitando-a à experiência litúrgica. Como assevera Neunheuser, a liturgia é a espiritualidade da Igreja. Assim, nosso estudo gravita em torno da Liturgia como locus privilegiado da Espiritualidade Eclesial.

\section{Pressupostos ao tema: espiritualidade}

Para melhor adentrar-se na temática da Espiritualidade Litúrgica, poder-se-ia mesmo apresentar alguns pressupostos que podem clarear a mesma. Esta prefação tende a ser uma ponderação teológica para o tema e uma busca da definição de mística.

\subsection{Pressupostos teológicos - primazia de Deus}

Hodiernamente, há uma degradação semântica do termo mística, associando-a a eventos absolutamente alheios a qualquer referência religiosa. A mística cristã pode cair em dois perigos, a saber, o racionalismo e o fideísmo. Quanto ao racionalismo, a Espiritualidade foi silenciada por pertencer à categoria dos sentimentos, do subjetivo, do metafísico. Foi silenciada, ainda, por uma experiência fideísta, em que, centrada no individualismo e pietismo, pode degenerar-se em fundamentalismo. A correta categorização mística escapa a ambos os extremos, a saber,

\footnotetext{
SC 10.

2 Como assevera o teólogo alemão Sudbrack, a assertiva de Rahner assinala que o termo "mística" não remete primordialmente a uma experiência rara ou a algum fenômeno extraordinário, mas ao lado existencial denso e inetenso da fé, ou seja, à experiência autêntica de Deus que brota do interior da existência. SUDBRACK, J. Mística: a busca do sentido e a experiência do absoluto. São Paulo: Loyola, 2007.
} 
fideísta e racionalista; assim, a mística é, antes, ação primaz de Deus em querer comunicar-se em uma experiência 'pessoal' com místico.

A mística cristã não é um movimento que brota de nossos desejos, de nossa busca de Deus, do esforço meramente humano de querer encontrar-se com um Deus à nossa disposição, pois, assim, cair-se-á no pelagianismo ou no sempelagianismo. Entretanto, o movimento é catabático, ou seja, a primazia é de Deus, Ele que dá o primeiro passo em direção ao homem, conforme nos ensina São João da Cruz - "Deus nos amou primeiro". No mesmo sentido, Santo Agostinho de Hipona assevera que - só $\mathrm{O}$ buscamos porque já $\mathrm{O}$ encontramos.

Dado que Deus foi o primeiro a amar-nos, ${ }^{3}$ Ele sempre detém a primazia da ação em direção ao homem. O cume desta primazia está na teologia da encarnação onde Jesus se fez carne e arnou sua tenda no meio de nós. Assim, assegura-se a primazia de Deus, bem como evita a tendência antropocêntrica. A mística cristã não é fruto do esforço e merecimento humano, é graça.

Com esta ponderação da primazia da graça, não se afirma uma passividade humana, ou a não colaboração humana na obra divina, nem se olvide dos aspectos históricos, religiosos, sociais e culturais que influem na experiência mística. $\mathrm{O}$ místico é alguém situado no tempo e no espaço. Nossa visão prescinde do essencialismo. ${ }^{4}$ Assim, o estudo e a exegese dos escritos e experiências místicas devem considerar o contexto histórico-social, religioso e psíquico da pessoa do místico.

Em suma, a teologia da graça ilunina a compreensão da experiência mística, balizando a centralidade de Deus. O primeiro passo é sempre de Deus, contudo, não se olvide da colaboração humana nesta experiência. O que a teologia da graça assegura é a ação salvífica de Deus que cria salvando e salva recriando o homem na Páscoa de Jesus.

\subsection{Pressuposto terminológico-lexical}

É relevante neste exórdio a definição de mística. ${ }^{5}$ Contudo, esta tarefa definitória esbarra na dificuldade de elaborar um conceito

3 Cf. 1 Jo 4, 10.

4 A visão essencialista interpreta os textos de forma literal, afirma que a experiência mística é imediata e realizada por Deus, prescindindo do influxo psíquico, social, religioso e de categorias mentais. Esta visão não leva em conta que toda experiência é uma síntese de presença e interpretação, segundo Paul Ricouer. Portanto, em nosso trabalho, adotar-se-á a interpretação fenomenológica e da teologia espiritual.

5 Acerca deste léxico, afirma Pádua: "A definição etimológia desses termos vem dos termos gregos derivados de myein, que significa a ação de fechar (os lábios ou os olhos), silenciar 
unívoco, quando o léxico definido é equívoco. Assim, encontram-se muitas definições.

Nesta busca definitória, coloca-se a questão: Será que a mística deve ser entendida partindo da 'êxtase', da superação da consciência ou simplesmente a partir da experiência 'ordinária' com Deus? Para Poulain ${ }^{6}$ a mística situa-se no 'extraordinário', em oposição à concepção de Garrigou-Lagrange, segundo o qual, a mística seria uma intensificação da fé e comum a todos os cristãos. Corroboram a tese de GarrigouLagrange, Karl Rahner, Hans Urs von Balthasar.

Nós assumiremos neste trabalho a definição de Velasco e Pádua, segundo os quais, a experiência mística pode ser entendida como uma experiência interior, fruitiva e imediata de união do fundo do sujeito com o todo - o universo, o absoluto, Deus ou o Espírito. ${ }^{7}$ Segundo Pádua, a experiência mística "[...] é realizada de maneira consciente, mesmo que transborde os esquemas da consciência que reagem à experiência ordinária, e provoca na pessoa alterações". ${ }^{8}$

Outro aspecto importante na teologia mística é a tríade lexical mistério, mística e mistico. Esta possui grande relevo, pois a tradição ocidental busca abarcar o fenômeno místico sob estes aspectos que devem ser compreendidos conjuntamente, ou ainda, aspectos que se tocam e interpenetram-se. Os léxicos da tríade querem expressar: o mistério é a origem fontal da experiência, o místico é o sujeito da experiência, por fim, a mística é a reflexão de ambas sob a sistematização da ratio. ${ }^{9}$

Por fim, outro termo que julgamos importante ponderar é mystérion. O termo mystérion é empregado no Novo Testamento, e deve ser visto sobre o fundo de seu emprego na cultura grega e na apocalíptica judaica. Pespectivamente querem exprimir uma reação a uma experiência que

e, metaforicamente, 'iniciar-se', perceber o caráter escondido de uma realidade através de um rito (experiência); donde mystes significa inciciado ou incorporado ao segredo do deus próprio de cada um dos cultos gregos; mystikós, significa o que diz respeito à iniciação; tá mystiká são os ritos de iniciação; mystikós advérbio que significa 'secretamente' e, finalmente, mystérion, o objeto de iniciação [...]”. PÁDUA. L. P. Mística, mística cristã e experiência de Deus. In: Atualidade Teológica 15 (2003) 344-373.

6 POULAIN, A. Des grâces d'oraison: traité de théologie mystique. Paris: Beauchesne, 1931.

7 VELASCO, M. El fenómeno místico. Estudio comparado. Madrid: Editorial. Trotta, 2003, p. 23.

8 PÁDUA. L. P. Mística, mística cristã e experiência de Deus. In: Atualidade Teológica 15 (2003) 344-373.

9 PÁDUA. L. P. Mística, mística cristã e experiência de Deus. In: Atualidade Teológica 15 (2003) 344-373. 
foge do pensamento discursivo, que não se pode formular com palavras, enquanto, na apocalíptica, fala-se em uma variedade de 'mistérios' - que são a origem da realidade oculta, transcendente a tudo que é e acontece especialmente daquilo que será revelado no 'fim dos tempos'. O que caracteriza seu emprego neotestamentário é a concentração no evento crístico. Esta virada lexical e semântica dá-se em Paulo em sua carta aos Colossenses, onde diz: “[...] o mistério divino, que é Cristo” ( $\mathrm{Cl} 2,2)$.

\section{Breve percurso histórico da Espiritualidade}

Após a apresentação dos pressupostos teológicos e lexicais, poder-se-ia, neste item, trabalhar um lacônico percurso pela história da espiritualidade nas mais variadas épocas eclesias.

Para tanto, percorrer-se-á o período patrístico e o medieval, perpassando à época tridentina até o século XIX, com o Movimento Litúrgico, que pode certamente ser denominado também de renovação litúrgico-espiritual, por fim, chegando ao Concílio Ecumênico Vaticano II. Não se busca neste item dar conta de todos os aspectos históricos apenas um resumido percurso na história da espiritualidade.

\section{Período patrístico ${ }^{10}$ e Medievo ${ }^{11}$}

No período patrístico, são típicas as catequeses mistagógicas dos santos padres. Estas catequeses mistagógicas ${ }^{12}$ partiam dos sacramentos da Iniciação Cristã - Barismo, Crisma e Eucaristia, para introduzir os neófitos nos "santos mistérios". Recorde-se do De mysteriis de Ambrósio

${ }^{10}$ Para um melhor aprofundamento: BERGAMINI, A. Cristo, festa da Igreja - o Ano Litúrgico. São paulo: Paulinas, 1994; MARTìN, J. P. A Liturgia da Igreja. Teologia, história, espiritualidade e pastoral. São Paulo: Paulinas, 2006.

${ }^{11}$ VAUCHEZ, A. A Espiritualidade na Idade Média Ocidental - Séculos VIII a XIII. Rio de Janeiro: Jorge Zahar Editor, 1995.

12 A Catequese Mistagógica é o processo de experiência e aprofundamento com a pessoa de Jesus Cristo. "O itinerário era estruturado segundo uma evolução cronológica, orientado para um processo de amadurecimento e de crescimento através de vários graus: o précatecumenato, um catecumenato mais intenso na última quaresma, a celebração dos sacramentos, a catequese mistagógica. [...] com vários outros elementos: ritos de inscrição, escrutínios, exorcismos, traditiones, celebrações sacramentais, etc.[...] Todo o caminho de iniciação tinha caráter tipicamente eclesial-comunitário, não só porque se realiza de modo público e institucionalizado, ou porque se enquadra no ano litúrgico [...] A catequese dos Padres é catequese estreitamente ligada à liturgia [...]". Cf. também MAZZA, E. La Mistagogia. Una teologia dela litugia in época patrística. Roma: Edizioni Liturgiche, 1988. 
de Milão e as Catequeses Mistagógicas de Cirilo de Jerusalém, as catequeses batismais de João Crisóstomo e Teodoro de Mopsuéstia, os sermões de Agostinho de Hipona e as homilias dos Papas Leão Magno e Gregório Magno.

Os séculos II-III conhecem o catecumenato, a celebração anual da Páscoa; o começo do culto dos mártires; desenvolve-se o Ano Litúrgico, com primazia do Domingo; constitui-se a Liturgia das Horas e as Vigílias noturnas; a Anáfora Eucarística possui uma forma própria - Anáfora de Hipólito de Roma.

A vida espiritual no período patrístico poder-se-ia caracterizar como mistagógica, vinculada à celebração dos Sacramentos, portanto, litúrgica. Era também eivada do Mistério Pascal. Não se olvide que neste período a Páscoa era a festa primordial dos cristãos, que a celebravam semanalmente na "Páscoa semanal" - o Domingo (dies dominicus - Kuriaké). O centro gravitacional da espiritualidade nos primeiros séculos girava em torno do Mistério Pascal ${ }^{13}$ e, do desenrolarse deste no Ano Litúrgico, a comunidade era introduzida mistagogicamente no Mistério de Cristo. ${ }^{14}$

O período denominado de medieval é visto como 'tempo de trevas' intelectual, político e religioso; contudo, os estudos recentes dos especialistas do medievo asseveram que esta tendência de julgar negativamento toda obra medieval é um erro. ${ }^{15}$

Delaruelle sintetiza como foi a espiritualidade no Medievo. Segundo o mesmo, esta foi uma "civilização da liturgia". ${ }^{16}$ Esta era rica

13 Afirma a Sacrosanctum Concilium no n. 6: "Nunca, depois do dia de Pentecostes, no qual apareceu ao mundo, a Igreja deixou de se reunir para celebrar o mistério pascal".

14 Transcreveremos alguns testemunhos patrísticos desde período: Justino na Apologia I "No dia chamado do Sol, reunimo-nos em um mesmo lugar [...] e fazemos a leitura das memórias dos apóstolos e dos escritos proféticos [...]. Portanto, todos nós nos reunimos no dia do Sol, porque é o primeiro dia em que Deus [...] plasmou o mundo, e no qual Jesus Cristo, nosso Salvador, ressuscitou dos mortos"; outro testemunho foi o martírio de 49 cristãos da Abissínia, onde encontramos o presbítero Saturnino afirmando diante do procônsul Anulino: "Nós devemos celebrar o dia do Senhor (Domingo)" e ainda, Emérito: "Sim, foi em minha casa que celebramos o dia do Senhor. Não podemos viver sem celebrar o dia do Senhor" e por fim, a jovem Vitória que afirma diante do tribunal: "Participei da assembleia porque sou cristã".

${ }^{15}$ Exemplo destes especialistas - GILSON, E. Études de philosophie médiévale, Université de Strasbourg, 1921; LUPI, J. E. P. Humanismo medieval (org. com Arno Dal Ri Júnior). Unijuí, 2005; Charles Homer Haskins - medievalista americano e o medievalista brasileiro da UFF Dr. Edmar Checon de Freitas e o Prof. Dr. Ricardo da Costa da UFES.

${ }^{16}$ DELARUELLE, E. La Gaule chrétienne à 1' époque franque. In: Revue d'Histoire de l'Eglise de France, 38, (1952) p. 64-72. 
em beleza estética; a própria arquitetura das catedrais expressavam o pensamento do homem religioso medieval que desejava representar a grandeza de Deus nas construções e na liturgia.

Neste período, a espiritualidade e a liturgia começam a caminhar para um certo ritualismo e, como assevera Vauchez, um acento é posto no indivíduo que passa a viver sua espiritualidade devocional e pessoal. Este era o clima espiritual dessa época. Outro aspecto é o acento na penitência compreendida como um novo tipo de relação "[...] entre o cristão e um Deus que dispensa as suas graças em troca de sacrifícios", como afirma Le Bras. ${ }^{17}$

A vida espiritual do Medievo pode ser laconicamente caracterizada como sendo expressa em orações particulares. As "[...] massas não tinham acesso a textos e se contentavam com algumas práticas religiosas: [...] abster-se de relações conjulgais nos tempos previstos, jejuar na quaresma, assistir à Missa dominical e pagar o dízimo"; ${ }^{18}$ o culto doméstico aos santos e anjos; uma expiritualidade com ênfase na angeologia e busca de proteção contra as incídias do demônio; florescimento da vida monástica - vita angelica, ${ }^{19}$ a Ordem de Cluny, os cistercienses, os cartuxos e outros, com acento na Lectio Divina, no Ofícios Corais rezados sete vezes ao dia, em que se recitavam os 150 Salmos em uma semana, silêncio e contemplação; as grandes campanhas missionárias que evangelizaram a Europa ${ }^{20}$ inclusive missões dos monges.

Grandes e importantes escolas de espiritualidade surgiram: os beneditinos, cistercienses, cartuxos, valombrosanos, olivetanos e outros, com uma espiritualidade monástica ${ }^{21}$ com matizes litúrgicas, escriturísticas e de vida escatológica; o acento na pobreza evangélica

${ }^{17}$ LE BRAS, G. Les pénitentiels irlandais. In: La vie quotidienne dans l'Empire caroligien. Paris (1973), p. 172-207.

18 VAUCHEZ, A. A Espiritualidade na Idade Média Ocidental - Séculos VIII a XIII. Rio de Janeiro: Jorge Zahar Editor, 1995, p. 22.

${ }_{19}$ Acerca do florescimento da vida monática com sua espiritualidade que influirá profundamente na espiritualidade medieval afirma Vauchez que "A fascinação exercida pela vida e pela espiritualidade monástica é compreensível em uma civilização para a qual o ato religioso por excelência era o culto (liturgia) prestado a Deus". VAUCHEZ, A. A Espiritualidade na Idade Média Ocidental - Séculos VIIIa XIII. Rio de Janeiro: Jorge Zahar Editor, 1995, p. 35-36.

${ }^{20}$ Para um maior apreensão da Evangelização da Europa, KONWLES. D.; OBOLENSKY, D. Nova história da Igreja. Petrópolis: Vozes, 1974, p. 13-22.

${ }^{21}$ Quanto aos traços da espiritualidade monástica, afirma Augé que "O monaquismo engendra a vida cristã como assemelhar-se a Cristo nos seus 'mistérios' para voltar com ele à imagem restaurada. $\mathrm{O}$ monaquismo atua assim, mantendo o sentido da atualidade permanente destes mistérios: certamente porque os reatualiza na prática; mas somente 
da escola franciscana com "os dois momentos privilegiados da vida de Jesus [...] na humilhação e na pobreza, são o nascimento e a cruz"; 22 na dominicana com o apresço pela ascese e o estudo e outras escolas como a devotio moderna.

Outro ponto de destaque são as mulheres místicas do século XII. Não só místicas, mas escritoras e conselheiras espirituais, tais como: Hildegarda de Bigen, Isabel de Schönau; as místicas de Helfta - Mectilde de Hackeborn, Gertrudes de Hackeborn e Santa Gertrude a Grande.

Em suma, no Medievo, a espiritualidade alcançou a máxima expressão na vida pessoal e social. ${ }^{23}$ Como afirma Bloch, "[...] nessa sociedade cristã nenhuma função de interesse coletivo parecia mais indispensável do que a dos organismos espirituais [...] O papel caritativo, cultual, econômico dos grandes capítulos, catedrais e dos mosteiros pode ter sido considerável". ${ }^{24}$

\section{Do Concílio de Trento ao século XIX}

O Concílio de Trento celebrado para responder ao movimento reformador protestante do século XVI, trouxe um novo vigor para a Igreja, na disciplina, na liturgia e na busca de reforma da vida cristã católica. Neste período a Igreja teve grandes místicos e escolas de espiritualidade. Como afirma Sánchez, "[...] não faltaram mestres de vida espiritual que buscaram e encontraram precisamente na liturgia, isto é, nos sacramentos e no ano litúrgico, estímulos para a formação da espiritualidade". ${ }^{25}$

pode reatualizar na medida em que eles influem nele com um peso concreto de vivência que é exatamente a celebração litúrgica (sacramento e palavra). (Para o monge) imitar Cristo e viver a celebração litúrgica são, portanto na realidade, a mesma coisa". AUGÉ, M. Liturgia - história, celebração, teologia e espiritualidade. São Paulo: Editora Ave Maria, 1996, p. 343.

${ }^{22}$ AUGÉ, M. Liturgia - história, celebração, teologia e espiritualidade. São Paulo: Editora Ave Maria, 1996, p. 344.

${ }^{23}$ Sem contar o florescimento "[...] da vida de devoção foi acompanhada pela instituição da 'Ordem terceira' para os leigos; forneceram assim os elementos da vida devota, orações regulares, exercícios simples de penitência, e a abstinência de certas distrações e prazeres, a homens e mulheres que viviam em família e administravam os negócios da cidade", como afirma Knowles. KNOWLES, M. D. A Idade Média (600-1500). Petrópolis: Vozes, 1974, p. 284. Para maior aprofundamento da Espiritualidade medieval, cap. XX - "A vida espiritual (I) e "A religião dos leigos", p. 272-287.

${ }^{24}$ BLOCH, M. La société féodale. Tomo I, 1939, p. 54.

${ }^{25}$ SÁNCHEZ, V. A Liturgia como fonte da espiritualidade cristã. In: CELAM. Manual de Liturgia IV: a celebração do Mistério Pascal. São Paulo:Paulus, 2007, p. 423. 
Como exemplos deste florescimento posterior ao Concílio, poder-seai apresentar o século XVI com os grandes, a saber, Santo Inácio de Loyola, Santa Teresa de Ávila e São João da Cruz. A escola de espiritualidade inaciana funda-se sob o seguimento de Cristo, nos Exercíos Espirituais. Inácio afirma que é "[...] motivo de elogio assistir frequentemente à Missa, como também aos cânticos, salmos e às prolongadas orações na Igreja $[\ldots],{ }^{26}$ demonstrando, assim, a ligação entre espiritualidade e liturgia.

Outros grandes nomes podem ser aventados: L. Thomassim (16191695), o beato Cardeal José Tomasi (1646-1713), Luís Antônio Muratori (1672-1750), J. M. Sailer (1751-1832), Antônio Rosmini (1797-1855) e o grande Abade beneditino Próspero Guéranger (1805-1875).

\subsection{Pio X e Lambert Beauduin - Movimento Litúrgico ${ }^{27}$}

Neunheuser afirma que o tema da "[...] espiritualidade litúrgica só se torna explícito no quadro recente do movimento litúrgico". ${ }^{28}$ Este pode

${ }^{26}$ LOYOLA, I. Gli scritti. Turin: Utet, 1977, p. 181.

${ }^{27}$ O Movimento Litúrgico, teve, desde a sua origem, uma eminente preocupação espiritual e pastoral da Liturgia. Recorde-se de alguns fatos que corroboem esta afirmação: a Abadia de Beuron com os irmãos Dom Mauro e Plácido Wolter, buscando ao lado da Regre Beneditina, que a Liturgia adquirisse o lugar central na 'ascese do monge'; Dom Anselm Schott, de Beuron, publica em 1884 o primeiro Missal latino-alemão; em 1914 o abade Dom Ildefonso Herwegen com um grupo de jovens celebra no mosteiro a Semana Santa com a Missa dialogada, pela primeira vez; a Missa celebrada versus populum, com a participação ativa do povo aconteceu em $1^{\circ}$ de agosto de 1926 no mosteiro de Maria Laach; Pius Parch, Cônego regular agostiniano tem como metas aproximar as classes mais simples do povo ao culto da Igreja, participação ativa na liturgia e devolver a Bíblia ao povo; o Congrés National des Oeuvres Catholiques de Malines de 1909. Este congresso expressou o desejo: 1. De recuperar o Missal como livro de espiritualidade; 2. A popularização do Missal traduzido e das Vésperas para serem rezadas aos Domingos nas paróquias; 3 . Retiros anuais para cantores das paróquias num centro de canto litúrgicopastoral; a criação em 1943 do Centro de Pastoral Litúrgica e do Congresso internacional Litúrgico-Pastoral de Assis; no Brasil o Movimento Litúrgico teve seu expoente em Dom Beda Keckeisen OSB, Dom Polycarpo Amstalden OSB, Frei Henrique G. Trindade OFM, Dom Tomas Keller OSB e no Abade da Abadia Territorial N. S. do Montserrat do RJ Dom Martinho Micheler, OSB. Este foi o primeiro a celebrar a Missa versus Populum no Brasil, a desenvolver a pastoral litúrgica do Domingo, a levar os leigos a rezarem a Liturgia das Horas como alimento espiritual, bem como foi D. Martinho o responsável por formar uma consciência litúrgica no meio laical. Dom Abade Martinho Micheler é o pioneiro do movimento litúrgico no Brasil; sua pessoa deve ser recordada sempre que se falar de Movimento Litúrgico no Brasil. Para uma melhor compreensão da vida e obra de Dom Abade Martinho Micheler - ISNARD, C. Dom Martinho: vida e obra do grande abade do Mosteiro de S. Bento do Rio de Janeiro. Rio de Janeiro: Lumen Christi, 1999 e sobre a história do Movimento litúrgico no Brasil - SILVA, J. A. O Movimento litúrgico no Brasil. Estudo histórico. Petrópolis: Vozes, 1983.

${ }^{28}$ SARTORE, D; TRIACCA, A. M. Dicionário de Liturgia. São Paulo: Paulinas, 1993, p. 371 (verbete: Espiritualidade Litúrgica). 
ser compreendido como um movimento de busca de renovação da vida espiritual dos cristão do mundo moderno, partindo da experiência litúrgica.

Contudo, já em 1903, o Papa Pio X, em seu moto próprio Tra le sollecitudini, revelava a preocupação por "[...] uma participação ativa nos sagrados mistérios e na oração pública e solene da Igreja". Segundo Augé, esta afirmação do Papa Pio X estabelece os fundamentos para o início da fase pastoral e espiritual do Movimento Litúrgico. Assim, Beauduin assume esta afirmação papal como o lema de seus estudos acerca da relação triádica: liturgia-espiritualidade-pastoral. Acerca da reforma de Pio X afirma Flores: "Esta reforma piana fez a Igreja sair de uma situação de imobilismo que durava havia séculos [...]". ${ }^{29}$

A renovação litúrgico-espiritual no século $\mathrm{XX}$ foi inaugurada pela obra profética de Dom Lambert Beauduin, ${ }^{30}$ OSB e de Dom Odo Casel, OSB, na Abadia beneditina de Maria-Laach e do Pe. Pius Parsch na Alemanha e na Áustria. Estes contribuíram para a compreensão da teologia litúrgica e da espiritualidade que brota da fonte litúrgica, com seus estudos patrísticos e pelo movimento de renovação bíblico e espiritual.

A Encíclica de Pio XII, Mediator Dei, de 1947, este documento pontifício foi decisiva para o movimento de renovação litúrgicoespiritual, já que estabelece alguns conceitos e reconhece a legitimidade do trabalho dos liturgistas do Movimento Litúrgico. Pio XII introduziu reformas parciais na liturgia, principalmente no que tange à Semana Santa. João XXIII leva a renovação até o Concílio Vaticano II.

Como nomes que perpetraram esta renovação litúrgico-espiritual na Igreja, poder-se-ia apresentar: primeiramente o Cardeal Ildefonso Schuster que com a "[...] sua produção literária, e com o exemplo de sua vida e de sua atividade pastoral [...] coloca-se nas origens dessa sensibilidade voltada para uma vida espiritual alimentada na riqueza da liturgia"; ${ }^{31}$ segundo nome seria Romano Guardini (1885-1968); por fim, destaca-se o nome do monge O. Casel (1886-1948) que "[...] ilustrou

${ }^{29}$ FLORES, J. J. Introdução à Teologia Litúrgica. São Paulo: Paulinas, 2006. p. 289.

${ }^{30}$ Dom Lambert Beauduin, OSB (1873-1960), monge na abadia de Mont-César, um dos pioneiros do Movimento Litúrgico, as suas principais obras litúrgicas: Essai de manuel fondamental de liturgie (1912-1921) - nesta, Beauduin, realizou um autêntico tratado teológico sobre a liturgia, sobre o culto da Igreja e a Trindade como objeto do culto. La piété de l'Église (1914), obra considerada como uma declaração pública do movimento litúrgico, como observa Rousseau em seu livro - Histoire du mouvement liturgique. Esquisse historique dépuis le début du XIX jusq’au pontifical de Pie X. Paris, 1945, Lex Orandi 3, p. 227.

${ }^{31}$ CELAM. Manual de Liturgia IV: a celebração do mistério Pascal. São Paulo: Paulus, 2007, p. 423-424. 
exaustivamente a riqueza teológica da espiritualidade litúrgica". ${ }^{32}$ Estes, renovaram a espiritualidade litúrgica. Partindo do Mistério de Cristo, celebrado nos mistérios da sacramentalidade litúrgica, chegam a propor uma união entre lex orandi, lex credendi e desembocando na lex vivendi.

Em suma, o Papa Pio X e Pio XII levam a Igreja a assumir o Movimento Litúgico como um movimento espiritual, em que se propõe como fonte e cume da vida espiritual dos fiéis. O Movimento LitúrgicoEspiritual do século XX desemboca no Concílio Ecumênico Vaticano II, que levará a cabo as intuições do Movimento, sendo este um tempo de renovação da vida eclesial.

\subsection{Concílio Ecumênico Vaticano II}

Tendo como fundamento o anterior trabalho do Movimento Litúrgico, o Concílio Ecumênico Vaticano II foi celebrado entre 1962-65 em Roma, como fruto desde, no que concerne à Liturgia, os padres conciliares aprovam a Constituição Dogmática sobre a Liturgia Sacrosanctum Concilium. ${ }^{33}$

A reforma litúrgica promovida pelo Concílio Vaticano II perpetrou a epifania da pastoral litúrgico-espiritual. Assim, a SC 10 assevera que todo o trabalho apostólico está ordenado para que todos, mediante a fé e o batismo, se reúnam em assembleia, louvem a Deus na Igreja e participem do sacrifício e da mesa Eucarística do Senhor. Esta seria a forma ordinária de aurir a espiritualidade, e a liturgia seria como que o locus primordial da espiritualidade - realização do louvor divino e da santificação do homem, num movimento ascendente (louvor à Trindade) e descendente (santificação-graça).

A SC 7 afirma que "toda celebração litúrgica, como obra de Cristo sacerdote e de seu corpo, que é a Igreja, é uma ação consagrada por

${ }^{32}$ Idem, p. 424.

33 A Constituição Sacrosanctum Concilium foi aprovada na aula conciliar do dia 14 de dezembro de 1963, sendo o primeiro documento promulgado. A maior contribuição foi situar a liturgia no contexto da Revelação, como Historia Salutis, "[...] obra da salvação, continuada pela Igreja, que se realiza na liturgia (SC 6). Desta forma a liturgia se apresenta como verdadeira 'tradição', ou seja, transmissão do mistério salvífico de Cristo através de um rito, de uma forma sempre nova e adequada à sucessão dos tempos e à diversidade de lugares”. Cf. Augé, Op. cit. p. 61. Foram cinco os critérios hermenêuticos que nortearam o esquema conciliar da Liturgia: 1. Máxima fidelidade à tradição da Igreja; 2. Limitação do texto aos princípios gerais da reforma; 3 . Normas práticas e rubricas, surgidas todas dos princípios doutrinais; 4. Necessidade da formação litúrgica do clero e 5. A promoção da participação dos fiéis. Cf. FLORES, t. Introdução à Teologia Litúrgica. São Paulo: Paulinas, 2006, p. 294. 
excelência, cuja eficácia, no mesmo título e grau, não é igualada por nenhuma outra ação da Igreja". A instrução Inter Oecumenici para uma exata aplicação da constituição sobre a sagrada liturgia, recordava que, antes de tudo, era necessário que todos estivessem convencidos de que a finalidade da SC não foi tanto modificar ritos e textos litúrgicos, mas antes promover a ação pastoral e uma espiritualidade que tivesse, como ápice e fonte, a Sagrada Liturgia. Assim, a espiritualidade deveria se concentrar na vivência do Mistério Pascal. ${ }^{34}$

O Concílio Vaticano II afirmou na Lumem Gentium: "Todos os fiéis cristãos são, pois, convidados e obrigados a procurar a santidade e a perfeição do próprio estado". ${ }^{35}$ Com essas palavras, a Igreja afirma que a santidade não é, como se pensava antes, um caminho para poucos eleitos de Deus, privilegiados; mas um caminho para todos os cristãos. Esse chamado é uma "vocação universal". Todos os batizados, portanto, sem exceção, são chamados à santidade. "Eles são justificados no Senhor Jesus - diz o Concílio - porquanto pelo batismo da fé se tornaram verdadeiramente filhos de Deus e participantes da natureza divina e, portanto, realmente santos". ${ }^{36}$ O Papa João Paulo II afirmou que "A Igreja não precisa de reformadores, mas de santos". Em outra ocasião, ele declarou aos catequistas: "Numa palavra, sede santos. A santidade é a força mais poderosa para levar a Cristo os corações dos homens". ${ }^{37}$

A partir das afirmações conciliares, surgem na Igreja experiências novas como o surgimento das 'novas comunidades' com uma espiritualidade própria, geralmente associações laicas e com ênfase pneumática. Entre elas poder-se-ia destacar: Focolares, Taizé, Canção Nova, Shalon e outras.

\section{Traços de uma Espiritualidade Litúrgica ${ }^{38}$}

Após a apresentação de uma lacônica história da Espiritualidade, poder-se-ia, neste item, trabalhar os traços de uma espiritualidade que brota da liturgia mesma.

${ }^{34}$ Cf. BERGAMINI, A. Cristo, festa da Igreja - o Ano Litúrgico. Sã paulo: Paulinas, 1994, p. 142.

${ }^{35}$ LG 41.

${ }^{36}$ LG 40.

${ }^{37}$ L'OSSERVATORE ROMANO. n. 24, 14 de agosto de 1992, p 22.

${ }^{38}$ No presente ítem, utilizar-se-á, o cap. 15 intitulado "A espiritualidade litúrgica" do renomado liturgista Matias Augé, para maior aprofundamento: AUGÉ, M. Liturgia história, celebração, teologia e espiritualidade. São Paulo: Ave Maria, 1996. 
Não se olvide que a espiritualidade pode ser entendida como o conjunto de experiência que grupos ou indivíduos fizeram e criaram. Dentre as escolas de espiritualidade destacam-se: a beneditina, a cisterciense, a cartuxa, a inaciana, a carmelita, a franciscana, a mariana, entre outras. A Igreja assumui todas estas experiências corroborando-as como caminhos de experiência de Deus. Ainda mais, a Igreja invita seus filhos no seguimento de Cristo via uma destas escolas de espiritualidade. Contudo, a Igreja, apesar de assumir em seu bojo estas escolas de espiritualidade, não faz de nenhuma delas a experiência eclesial. A Espiritualidade da Igreja é Espiritualidade Litúrgica, como assevera Iraburu. ${ }^{39}$

Augé, apresentando os traços da espiritualidade litúrgica, assevera que, ao falar-se de liturgia, está referindo-se ao momento celebrativo e mistagógico, portanto, do mistério. Segundo o autor, a celebração litúrgica é "[...] um ambiente concreto de experiência espiritual cristã, uma espiritualidade concreta [...]" ${ }^{40}$ Assim, é no ambiente concreto e na forma ordinária da celebração litúrgica que o cristão aure a espiritualidade, a ressignifica e alimenta.

Por fim assevera Augé:

[...] a experiência espiritual cristã não pode considerar a celebração nem como estrutura facultativa, nem como estrutura intermediária, mas sim como um momento que alicerça, gerador da própria experiência. $^{41}$

A experiência espiritual cristã encontra ordinariamente na Liturgia a referência, as balizas, a fonte e o cume de sua realização. Esta contudo, não é uma experiência ritualista, mas uma celebração prenhe do mistério - o próprio Deus. Esta experiência espiritual litúrgica não se prende na celebração mas transborda na vida. Cabe muito bem a compreensão antiga da lex orandi, lex credendi, e da lex vivendi.

Outro traço da Espiritualidade Litúrgica é a sequela Christi, centro de toda ação litúrgica, que conduz o orante a uma atitude e a um estilo de vida que se baseia na assimilação ou identificação com a pessoa de Cristo. Este seguimento de Cristo, segundo Augé, é produzido:

\footnotetext{
${ }^{39}$ Cf. IRABURU, J. M. Espiritualidad católica. Madrid: [?], 1982.

40 AUGÉ, M. Liturgia - história, celebração, teologia e espiritualidade. São Paulo: Ave Maria, 1996, p. 339.

${ }^{41}$ Ibidem.
} 
[...] pelo batismo e pela confirmação e a seguir nutridos pela plena participação à Eucaristia, aos sacramentos em geral e à oração da Igreja; tudo isso no âmbito fundamental do Ano Litúrgico $[. . .]^{42}$

No quadro da Liturgia o fiel, pela Iniciação Cristã, é inserido no Mistério Trinitário pela mistagogia das celebrações dos sacramentos e sacramentais no contexto do Ano Litúrgico. Na Liturgia o mistério de Cristo é sacramentalmente celebrado e vivido de forma integral. Em todo Opus Dei celebra-se fundamentalmente o Mistério PascalPentecostal de Cristo.

Pádua recolhe de vários teólogos as características da experiência mística e as sintetiza. Segundo a mesma, é experiência de Algo ou Alguém que sobrepassa a pessoa e que se revela mais real do que o que se considera a realidade; é totalizante da presença do Todo; ultrapassa a vida ordinária; provoca uma profunda alteração na vida da pessoa com apelo ético e existencial; é uma experiência gratuita, onde não contam os mérios do místico; outro elemento é a passividade, é "Deus o mistério que invade a existência humana"; é uma experiência inefável o que decorre da dificuldade do místico expressar com palavras o inefável e indizível da experiência mística; surge no místico uma nova consciência, a intuitiva e unitiva; por fim, o místico não absolutiza sua esperiência e não a desvincula do amor. ${ }^{43}$

\section{A lex orandi como locus da Espiritualidade Eclesial ${ }^{44}$}

Marsile, em sua obra I segni del mistero di Cristo, ${ }^{45}$ assevera que a Liturgia como "o ponto mais alto para o qual tende toda a ação da Igreja e, ao mesmo tempo, a fonte da qual procede toda a sua força", ${ }^{46}$ somente dela poderia aurir a Igreja sua espiritualidade.

\footnotetext{
42 Ibidem.

${ }^{43}$ PÁDUA. L. P. Mística, mística cristã e experiência de Deus. In: Atualidade Teológica 15 (2003) 344-373.

${ }^{44}$ Para um maior aprofunadmento da temática: MARTÌN, J. P. A Liturgia da Igreja. Teologia, história, espiritualidade e pastoral. São Paulo: Paulinas, 2006; BRASSO, G. Liturgia y Espiritualidad. Montserrat: [?], 1956; TRIACCA, A. M. Per una definizione di 'spiritualità' cristiana dall'ambito liturgico. In: Not 272 (1989), 277-288; TENA, P. Liturgia y espiritualidad, Cuestión actual? In: Ph 62 (1971), 157-166; CELAM. Manual de Liturgia IV: a celebração do mistério Pascal. São Paulo:Paulus, 2007, p. 421-444; TOLDO, R. L’anno litúrgico come itinerário permanente dela comunità Cristiana. In. Rivista Liturgica, n. 4, ano 1988, p. 531-553.

${ }^{45}$ MARSILI, S. I segni del mistero di Cristo. Teologia liturgica dei sacramenti. Roma. Edizioni Liturgiche, 1987, p. 505.

${ }^{46}$ SC 10.
} 
A Lex orandi torna-se o locus privilegiado da Espiritualidade Eclesial. A Igreja faz da Liturgia sua espiritualidade. Contudo, a Espiritualidade Liturgia não pode ser entendida como oposta ou ainda como concorrência com as demais escolas de espiritualidade, como bem corrobora Augé:

Observamos de imediato que esta espiritualidade (a litúrgica) não deve ser interpretada como oposição ou concorrência com outras espiritualidades, mas sim como o substrato comum de toda a espiritualidade cristã, da forma como ele é revelado pela Igreja na sua liturgia. ${ }^{47}$

O valor da liturgia na vida eclesial faz com que a mesma seja o ponto de referência obrigatória de qualquer autêntica experiência espiritual. Sendo a Liturgia o lugar epifânico do Mistério, que na liturgia é uma Pessoa - Jesus Cristo, ela é o ponto comum para onde convergem as 'escolas de espiritualidade'. Na Liturgia, estas 'espiritualidades' encontram as balizas e discernimento.

A prórpia vida do orante na Liturgia torna-se um 'culto espiritual'. A vida cristã como este culto "no Espírito e na verdade", ${ }^{48}$ concretiza-se na liturgia que é o exercício do múnus sacerdotal de Jesus para santificar os homens e glorificar à Deus. ${ }^{49}$

Esta Espitualidade que brota da Liturgia não é uma forma de vida facultativa, mas o substrato básico e geral, comum às 'escolas de espititualidades', como afirma Martín, "sem excluir modelos concretos, segundo as diversas escolas históricas de espiritualidade, a liturgia constitui um fator fundamental de todas elas". ${ }^{50}$

\section{Características da Espiritualidade Litúrgica ${ }^{51}$}

A Liturgia manifesta a Espiritualidade própria da Igreja e como assevera Augé "[...] pertence de fato ao tesouro comum da

\footnotetext{
${ }^{47}$ AUGÉ, M. Liturgia - história, celebração, teologia e espiritualidade. São Paulo: Ave Maria, 1996, p. 339.

${ }_{48} \mathrm{Jo} 4,23 ; \mathrm{Rm} 12,1$.

49 SC 7.

${ }^{50}$ MARTÍN, J. L. A Liturgia da Igreja. Teologia, história, espiritualidade e pastoral. São Paulo: Paulinas, 2006, p. 482-483.

${ }^{51}$ AUGÉ, M. Liturgia - história, celebração, teologia e espiritualidade. São Paulo: Ave Maria, 1996 p. 347-352.
} 
vida espiritual cristã". ${ }^{52}$ Para tanto, examinar-se-ão as características fundantes que tocam os aspectos da Espiritualidade Litúrgico-Eclesial. A Espiritualidade é bíblica, cristológica, eclesial e mistagógico-pascal.

\subsection{Espiritualidade Bíblica}

Agostinho de Hipona, no Sermão 85,1, afirma que "A boca de Cristo é o Evangelho, Reina no céu, mas não cessa de falar na terra". ${ }^{53}$ Assim a liturgia cristã é atualização ritual do evento real da salvação, que é Cristo. Ele continua falando na assembleia reunida. Bergamini assevera que a liturgia, portanto, “[...] está para a Escritura, assim como a realidade de Cristo está para o seu anúncio". ${ }^{4}$

A espiritualidade liturgica ${ }^{55}$ é eminentemente bíblica, e precisamente porque bíblica, é histórico-profética; é sensível a Revelação de Deus que se realiza na história humana, tornando-a Historia Salutis. O Mistério de Cristo continua a atuar no hodie da sacramentalidade da Igreja, pois, receptora do agir salvífico de Cristo, a Igreja ${ }^{56}$ é sacramento universal de salvação, principalmente quando na assembleia litúrgica se faz a anmaneses da morte e Ressurreição de Cristo na leitura proclamativa das Sagradas Escrituras. Assim, afirma a Introdução ao Lecionário:

A Igreja anuncia o único mistério de Cristo cada vez que, na celebração litúrgica, proclama seja o Antigo seja o Novo Testamento. [...] Cristo é o centro e a plenitude de toda a Escritura, como de toda a celebração litúrgica: por isso, é preciso que todos aqueles que procuram a salvação e a vida recorram às fontes da Escritura. Quanto mais se penetra no vivo da celebração litúrgica,

52 Idem, p. 347.

${ }^{53}$ AGOSTINHO Sermão 85,1.

54 Bergamini, A. Cristo, festa da Igreja - o Ano Litúrgico. São Paulo: Paulinas, 1994, p. 31.

55 “A espiritualidade litúrgica é essencialmente bíblica, isto é, baseada na Bíblia como Palavra de Deus celebrada e atualizada nos sinais litúrgicos. O Lecionário da Missa, o Ofício Divino e o dos sacramentos e sacramentais oferecem os conteúdos salvíficos concretos para a santificação dos homens e para o culto a Deus. Nesse sentido, essa espiritualidade é também histórica e profética, enquanto leva a penetrar no significado savífico e escatológico dos acontecimentos da história da salvação cumprida em Cristo e proclamada na existência dos batizados". MARTín, J. L. A Liturgia da Igreja. Teologia, história, espiritualidade e pastoral. São Paulo: Paulinas, 2006, p. 483-484.

${ }^{56}$ Bergamini afirma que "Como Cristo nunca está do seu corpo, que é a Igreja, pois o seu mistério deve ser participado e interiorizado pelos cristãos, os textos da Escritura possuem esta terceira profundidade, que pode ser chamada de profundidade cristã. Esse aspecto é de muita importãncia na relação entre liturgia e vida espiritual". BERGAMINI, A. Cristo, festa da Igreja - o Ano Litúrgico. São Paulo: Paulinas, 1994, p. 35. 
tanto mais se percebe a importância da palavra de Deus; o que se diz da primeira pode-se afirmar também da segunda, porque ambas evocam o ministério de Cristo e ambas, a seu modo, o perpetuam..$^{57}$

Portanto, a Igreja, no seu Ordo Lectionum Missae, apresenta aos fiéis reunidos em assembleia para participar da duplice mesa da Palavra ${ }^{58}$ e da Eucaristia, um tesouro para a maior frutuosidade espiritual dos fiéis. Durante todo o Ano Lítúrgico, a Igreja escuta a Palavra do Senhor e busca vivê-la "em atenção às suas palavras".

A Sacrosanctum Concilium no n. 7, afirma que Cristo “[...] está presente na sua palavra, pois é ele quem fala quando na Igreja se lê a Sagrada Escritura", contudo, Paulo VI, em sua Encíclica Mysterium Fidei, explicita o que o Concílio afirmou, corroborando que se trata de uma presença não virtual, mas verdadeira e real. Assim, a Liturgia da Palavra proclamada é presença real de Cristo, é alimento espiritual. ${ }^{59}$

Em suma, a Palavra de Deus, proclamada na ação litúrgica, deixa de ser uma palavra consignada por escrito para tornar-se uma Palavra de anúncio-realização, pois esta Palavra é sacramentalmente realizada na Liturgia pelo Espírito Santo, no hodie litúrgico-salvífico. Acerca desta atualização pneumática da Escritura na ação litúrgica, pondera Augé que o "[...] acontecimento que se lê na Escritura é o mesmo que se realiza na liturgia. [...] são o anúncio permanente da salvação presente e atuante no ministério litúrgico".

${ }_{57}$ Introdução ao Lecionário, n. 5. In: LECIONÁRIO. São Paulo: Paulinas, 1994.

${ }^{58} \mathrm{O}$ movimento profético apresenta-nos alguns textos que mostram a necessidade de comer a Palavra de Deus. O exemplo mais enfático é do profeta Amós: "Eis, virão dias - diz o Senhor Deus - durante os quais mandarei a fome na terra, não fome de pão, nem sede de água, mas sede de escutar a palavra do Senhor" $(A m 8,11)$.

59 Afirma Matias Augé: “As leituras estão em íntima relação com a ação sacramental, participam da plenitude da realidade (de presença real do mistério), que é própria do mistério eucarístico. Portanto o hodie da liturgia da palavra encontra a sua plenitude de conteúdo no mistério de Cristo sacramentalmente presente na Eucaristia”. Cf. AUGÉ, op. cit., p. 139. Ainda acerca do hodie na liturgia, afirma a Abadessa Madre Paula Iglésias: “[...] a atualização sacramental do Mistério celebrado no rito litúrgico, no curso do qual a obra da Revelação de Deus em Cristo nos é tornada presente para que dela participemos de forma imediata e viva. É o Hoje da Liturgia que nos insere no Mistério de Cristo revelado nas Escrituras. É o mesmo Hoje pronunciado outrora por Cristo na sinagoga de Nazaré que tem a sua repercussão no "hoje litúrgico da Igreja"”. IGLÉSIAS, Paula. Uma Lectio Divina: na Bíblia, na História de Israel, na Liturgia. Juiz de Fora: Edições Subiaco, 2010. p. 123. 


\subsection{Espiritualidade Trinitária ${ }^{60}$}

Dado que a Liturgia tem como centro gravitacional o Mistério do Deus Uno-Trino onde giram todas as suas celebrações, que intentam render culto de adoração, a Espiritualidade demandada dela somente poderia ser Trinitária.

Não nos olvidemo de que a Liturgia estrutura-se num movimento - anabático e catabático - de subida e descida. Dos homens (louvor, adoração, eucaristia) ao Pai, pelo Filho, no Espírito - subida. Bem como, num movimento descendente, do Pai (eleição-graça-salvação), pelo Filho, no Espírito, aos homens.

A estrutura anabático-catabática da liturgia corrobora-se pelo fato de que a relação do Deus Uno-Trino, com a humanidade, exerce-se num movimento ininterrupto de constante kenoses. ${ }^{61} \mathrm{O}$ Pai esvazia-se de si para gerar eternamente seu amado Filho. Este, por sua vez, tornase a imagem encarnada do 'empobrecimento', assumindo a condição humana, na carne, fazendo-se um 'ser-para'. Grandes implicações esta estrutura trará para a espiritualidade, ou seja, a mesma é antes de tudo uma relação Trinitária de diálogo anabático-catabático.

A teologia redescobriu no movimento litúrgico a estrutura fundamental da oração litúrgica. Esta, ou é trinitária ou não será verdadeiramente cristã. Também possibilitou à teologia trinitária perceber-se na lex orandi, visto que, a lex credendi possui sua fonte

${ }^{60}$ MARTÍN, J. L. A Liturgia da Igreja. Teologia, história, espiritualidade e pastoral. São Paulo: Paulinas, 2006; VELASCO, M. El fenómeno místico. Estudio comparado. Madrid, Editorial. Trotta, 2003; AUGÉ, M. Liturgia - história, celebração, teologia e espiritualidade. São Paulo: Ave Maria, 1996; MARSILI, S. Mistero di Cristo e liturgia nello Spirito. Cidade do Vaticano: Libreria Editrice Vaticana, 1986.

${ }^{61}$ Em sua obra intitulada Mysterium Paschale, o grande teólogo alemão, Hans Urs von Balthasar, busca uma nova imagem do Deus Uno-Trino. Esta é perpassada pela chave de leitura do conceito grego 'kenoses'. Para o autor, a relação intratrinitaria é por essência quenótica, visto que há um esvaziamento eterno na Trindade. Esta quenose trinitária, para von Balthasar, constitui "[...] a pessoa do Pai e, ao mesmo tempo, do Filho e a do Espírito Santo" (Mysterium Paschale, p. 10). A Encarnação de Cristo para Balthasar continua sendo o expoente deste esvaziamento trinitário, como assevera a teologia neotestamentária. No entanto, o teólogo alemão transborda a tradicional teologia paulina da carta aos Filipenses (F1 2,6-11) às demais Pessoas da Trindade. Na verdade, von Balthasar, mais do que aplicar à Trindade o conceito de 'esvaziamento', faz deste, a essência e o caminho teológico para adentrar no mistério da Trindade, contemplando o Mistério do Cristo. BALTHASAR, Hans Urs von. El misterio pascual. In: Mysterium Salutis. Fundamentos de la dogmátima como historia de la salvación 3/1. Madrid, 1969. 
e ápice no ato celebrativo. Não podemos separar o 'ato de fé' do 'ato celebrativo' e o 'ato de viver'. ${ }^{62}$

A imagem esvaziada do Filho na ceia-crucifixão-morte-descida aos infernos, encontra seu máximo despojamento no sopro de seu hálito pneumático sobre a Igreja e o mundo. O Espírito Santo doado por Cristo pode ser vislumbrado como o ícone vivo deste esvaziamento contínuo da Trindade, que não cessa de doar-se ao homem. O Espírito Santo é catábase, ou seja, é descida, a Igreja na Liturgia ora pedindo uma epíclese pneumática. ${ }^{63}$ É por obra do Espírito Santo que a liturgia é a celebração no tempo e no espaço do opus redemptionis, ${ }^{64}$ ou seja, o plano históricosalvífico realizado pelo Pai em Cristo é atualizado sacramentalmente em cada ação litúrgica. Como tal, a liturgia é essencialmente epifania do Espírito de Cristo Ressuscitado. ${ }^{65}$

Para uma melhor visualização da estrutura trinitária das orações litúrgico-eclesiais, observemos alguns textos litúrgico-eucológicos:

Concedei-nos, ó Deus todo-poderoso, iniciar com este dia de jejum o tempo da Quaresma, para que a penitência nos fortaleça no combate contra o espírito do mal. Por nosso Senhor Jesus Cristo, vosso Filho, na unidade do Espírito Santo. ${ }^{66}$

${ }_{62}$ Próspero de Aquitânia, numa célebre fórmula: Legem credenti statuat lex supplicandi, atribui à liturgia um valor regulador em matéria de fé. A utilização deste critério é devedor da antiguidade patrística, representada pela Didaqué, e continuada nos textos que se referem à disciplina e organização das comunidades protocristãs, como a Traditio Apostolica de Hipólito de Roma. Os santos padres que se utilizam são: Orígenes, Tertuliano, Cipriano, Ireneu e Basílio. "Um elemento litúrgico sobre o qual se apoiam fortemente os Santos Padres, a começar por Orígenes, são as interrogações sobre a fé que precede o batismo, em vista do mistério da Trindade; isto vale também para outras fórmulas litúrgicas, como as doxologias e as anáforas eucarísticas". PELLEGRINO, Michele. Dicionário Patrístico e de Antiguidades Cristãs. Petrópolis: Vozes, 2002. Verbete: Liturgia e Padres, p.835.

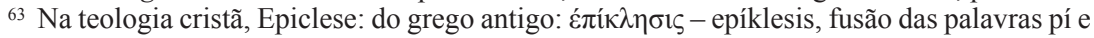
kaleô: "chamar sobre", é a oração de invocação que pede a descida do Espírito Santo nos sacramentos.

${ }^{64}$ Buscando uma explicitação do termo - opus redemptionis, seria indispensável debruçarse sobre os textos eucológicos da própria liturgia e nesta, encontra-se: "quoties huius commemoratio celebratur, opus nostrae redemptionis exercitur" (toda vez que celebramos este memorial do sacrifício do Senhor, realiza-se a obra de nossa salvação). Assim, a liturgia torna-se escola da fé e da práxis, a explicitação da teologia da Redenção, justificação e sacramentologia. Encontra na liturgia sua lex celebrandi.

${ }_{65}$ "É igualmente por obra do Espírito Santo que toda ação litúrgica manifesta e realiza a presença de Cristo e que a 'memória' do mistério salvífico não se limita a ser simplesmente uma piedosa recordação, mas é de fato 'anamnese' histórico-salvífico. Impõe-se, assim, a necessidade do estudo da presença e da ação do Espírito Santo na liturgia”. SARTORE, D.; TRIACCA, A. M. Dicionário de Liturgia. São Paulo: Paulinas, 1993, p. 359.

${ }^{66}$ Oração de Coleta da Quarta-Feira de Cinzas - início do Tempo Quaresmal. Cf. MR. 
Ouvi, ó Pai, as nossas preces para que, ao afirmarmos nossa fé na ressurreição do seu Filho, se confirme também nossa esperança na ressurreição de vosso servo N. Por nosso Senhor Jesus Cristo, vosso Filho, na unidade do Espírito Santo. ${ }^{67}$

Deus Pai de misericórdia, que pela morte e ressurreição do vosso Filho, enviou o Espírito Santo para a remissão dos pecados, te conceda pelo ministério da Igreja, o perdão e a paz. Eu te absolvo dos teus pecados em nome do Pai, do Filho e do Espírito Santo. ${ }^{68}$

Após, a observação destas orações litúrgicas, conclui-se que a Liturgia cristã, bem como a espiritualiade, é patrofinalizada, cristomediatizada e pneumato-amalgamada. Respectivamente, estas querem expressar o seguinte conceito teológico: toda a oração se dirige ao Pai, enquanto princípio fontal e meta de todo o agir humano. É mediada pelo Cristo - Jesus é o sumo e eterno sacerdote da Nova Aliança e o único mediador. ${ }^{69}$ Assim, como é pela ação do Espírito Santo que se 'forma' a oração em nós, assim, como afirma Paulo: “[...] o próprio Espírito ora em nós com gemidos inefáveis". ${ }^{70}$ "Tudo vem do Pai pelo Filho no Espírito; e tudo, no mesmo Espírito, pelo Filho ao Pai". ${ }^{71}$

A estrutura trinitária da liturgia conduz o orante a uma experiência mística com a Trindade; contudo, esta só é possível pela ação do Espírito Santo. Aquiles Triacca afirma:

Se a celebração litúrgica não for sinal do Espírito, ela nada será. Com efeito, a verdadeira essência da ação litúrgica consiste em serepifania-do-Espírito Santo. Ora, o Espírito, por meio da Escritura, foi iconógrafo, isto é, operou no hagiógrafo a revelação do ícone do Pai, que é Jesus Cristo (cf. 2Cor 4,4; Cl 1,15). Em Maria, ele foi iconoplasta, ou seja, é plasmador do próprio ícone (do Verbo). $\mathrm{Na}$ ação litúrgica, ele simultaneamente iconógrafo, iconoplasta e iconóforo, isto é, portador do ícone do Pai presencializado e vivificado. ${ }^{72}$

\footnotetext{
${ }^{67}$ Oração das Vésperas do Ofício dos fiéis defuntos - Liturgia das Horas. Cf. LH.

${ }^{68}$ Fórmula da absolvição - Rito da Penitência. Cf. MR.

${ }^{69} \mathrm{Cf} . \mathrm{Hb} 8,6$.

${ }^{70} \operatorname{Rm} 8,27$.

${ }^{71}$ A estrutura da liturgia e da doxoadoração da práxis cristã: cf. VAGAGGINI, Cipriano. Il senso teologico della liturgia, 5. ed. Roma, 1968.

72 TRIACCA. A. Espirito Santo. In: SARTORE, D.; TRIACCA, A. M. Dicionário de Liturgia. São Paulo: Paulinas, 1993, p. 371 (verbete: Espírito Santo).
} 
Portanto, o Espírito Santo plasma, porta e escreve o ícone da Trindade no orante da prece litúrgica. A ação litúrgica pela epíclese do Espírito Santo é apofática, no sentido de contemplar o Mistério, sem racionalizá-lo com o excesso do discurso teológico.

A estrutura da oração litúrgica nos vários Ordos, sacramentais e livros litúrgicos, segue sempre a doxologia Trinitária ao Pai, pelo Filho no Espírito. Esta estrutura Trinitária é normativa e modelo para toda oração cristã. Pode-se mesmo afirmar que a lex orandi e a lex credendi transbordam na moral de atitude cristã, pois a vida do cristão é relação com a Trindade - lex vivendi. Em suma, a Espiritualidade Litúrgica é patrofinalizada, cristomediatizada e pneumato-amalgamada.

\subsection{Espiritualidade eclesial e sacramental}

A assembleia litúrgica é epifania da Igreja que se concretiza numa comunidade que, em torno do altar - Christus altare est - celebra os louvores sacrificais e laudativos ao Pai, ao Filho e ao Espírito Santo. Assim, pela Liturgia, a dimensão eclesial (comunitária) da experiência espiritual se destaca.

Como assevera o Concílio Vaticano II, a Igreja é sacramento universal de salvação, portanto, a Igreja é sacramento de Cristo, que é sacramento do Pai. A Espiritualidade Litúrgica é eclesial e sacramental. Esta dimensão eclesiológica da liturgia se torna manifesta nas celebrações dos sacramentos, dos quais a Igreja é ao memso tempo ministro e sujeito, como corrobora Augé. ${ }^{73}$

Esta dimensão eclesiológica incidindo na espiritualidade é perceptível nos místicos. Exemplo disto é o que afirma São João da Cruz: "[...] não ser minha intenção apartar-me da sã doutrina e sentido da Santa Madre Igreja Católica. Submeto-me e resigno-me inteiramente, não só à sua autoridade [...]". ${ }^{74}$

Acerca da sacramentalidade, afirma Augé:

Os sacramentos da Igreja, que constituem a liturgia, são meios de participação direta e eficaz aos atos redentores de Cristo, especialmente pela sua morte e ressurreição. Deles nasce uma assimilação com a pessoa de Cristo, ou 'imitação' na própria vida

\footnotetext{
${ }^{73}$ AUGÉ, M. Liturgia - história, celebração, teologia e espiritualidade. São Paulo: Ave Maria, 1996, p. 349.

${ }^{74}$ SÃO JOÃO DA CRUZ. Subida do Monte Carmelo. In: Obras completas. Petrópolis: Vozes, [?], p. 136.
} 
dos mistérios celebrados na liturgia. É um assunto que aperece em muitas orações: imitar ou testemunhar nas obras o que é celebardo no sacramento. Assim, por exemplo, a coleta da sexta-feira na Oitava de Páscoa: 'Concedei-nos testemunhar na vida o mistério que celebramos na fé'. Neste sentido a espiritualidade litúrgica se transforma num estímulo permanente para o fiel tornar conforme à sua vida aquilo que está celebrando. ${ }^{75}$

Os sacramentos celebrados pela Igreja e para a Igreja conduzem para uma espiritualidade de imitação de Cristo, sendo seus seguidores e testemunhas da Ressurreição.

\subsection{Espiritualidade mistagógica}

A Liturgia como opus crístico-pneumático e eclesial realiza as palavras sálmicas: "Vinde, agora, bendizei ao Senhor Deus, vós todos, servidores do Senhor, que celebrais a liturgia no seu templo, nos átrios da casa do Senhor", ${ }^{76}$ de forma especial na celebração dos Sacramentos e da Liturgia das Horas. ${ }^{77}$ Sendo a Liturgia este opus Dei e também opus hominibus, não há na mesma espaço para apresentar uma ideia para participação ativa, ou ainda, uma moral, mas antes, é a Liturgia momento próprio para experimentar o Mistério salvífico de Deus.

Neste sentido, poder-se-ia, chamar a Liturgia de mistagógica, pois epifania o mistério e conduz o orante mistagogicamente ao encontro do Mistério. No cristianismo o Mistério não é uma experiência, ou ainda,

${ }^{75}$ AUGÉ, M. Liturgia - história, celebração, teologia e espiritualidade. São Paulo: Ave Maria, 1996, p. 349.

${ }^{76}$ Sl 133/134, 1. Bíblia de Jerusalém: antigo e novo testamento. São Paulo: Paulus, 2002. Todas as citações deste trabalho monográfico serão da referida tradução de Jerusalém.

77 O Officium Divinum renovado foi promulgado por Paulo VI, com a Constituição Apostólica Laudis Canticum de $1^{\circ}$ de novembro de 1970. Augé afirma que "[...] a Liturgia das Horas, sendo oração pública e comunitária do povo de Deus, faz parte do mistério da Igreja e é uma manifestação e expressão especial: 'O louvor da Igreja não é reservado, nem por sua origem, nem por sua natureza, aos clérigos e aos monges, mas pertence a toda a comunidade cristã' [...] Somente a Liturgia das Horas manifesta plenamente toda a Igreja orante como tal e a sua permanência constante na oração, e somente ela a realiza da forma mais espontânea [...]. Esta oração é a mesma que a Igreja considera como sua por um título especial, isto é, como Corpo Místico total de Cristo". AUGÉ, M. Liturgia história, celebração, teologia e espiritualidade. São Paulo:. Ave-Maria, 1996. p. 265. Não se olvide que a celebração da Liturgia das Horas prepara e prorroga no tempo-kairótico o Mistério Pascal, desta teologia do Opus Dei que se afirma a íntima ligação entre a Liturgia das Horas e a Celebração Eucarística. Para uma melhor compreensão da teologia e história da Liturgia das Horas: BECKHÄUSER, Alberto. O Sentido da Liturgia das Horas. Petrópolis: Vozes, 1996. 
uma moral, até mesmo uma filosofia, mas é uma Pessoa - Jesus Cristo, mistério de Deus revelado aos homens. Caro ao período patrístico, recuperado no Movimento Litúrgico e levado a cabo na hodierna teologia litúrgica é a mistagogia, que segundo Mazza, é:

[...] um ensinamento destinado a provocar a compreenção do que os sacramentos significam para a vida, mas que pressupõe a iluminação da fé, que brota dos próprios sacramentos e o que se aprende vivendo conforme aquilo que os sacramentos significam para a vida. ${ }^{78}$

Assim, nasce da própria mistagogia litúrgica a Espiritualidade da Igreja, que, ao longo do Ano Litúrgico, permite-nos experimentar sempre mais profundamente o mistério de Cristo, atualizado sacramentalmente pelas ações litúrgicas nos sacramentos e sacramentais. Como assevera Augé, precisamente por atualizar o mistério que é Cristo mesmo, resulta a dimensão 'mística' da espiritualidade, como "[...] atualização do mistério celebrado na vida do cristão". ${ }^{79}$ Para o autor, este mistério que se celebra na ação Litúrgica e "[...] escondido nos séculos em Deus, que Ele quis manifestar e comunicar aos homens no seu Filho, morto e ressuscitado, com a efusão do Espírito". ${ }^{80}$

\section{A liturgia Schola Oratio - o Espírito Santo mestre de oração}

A Liturgia como Espiritualidade da Igreja é uma Schola Oratio. Esta 'escola de oração' faz progredir a oração pessoal e comunitária, pois a Liturgia é a 'Igreja em oração'. Martín assim assevera acerca da Liturgia como Schola Oratio:

Em todo caso, a liturgia, com seu caráter mistérico e eclesial, é 'escola de oração' para a totalidade dos membros do povo de Deus. Com efeito, trata-se de educar na oração a partir da celebração litúrgica, para que não existam comportamentos estanques na

\footnotetext{
${ }^{78}$ MAZZA, E. La mistagogia. Uma teologia della liturgia in epoca patrística. Roma: Edizione Liturgiche, 1988. In: AUGÉ, M. Liturgia - história, celebração, teologia e espiritualidade. São Paulo: Ave Maria, 1996, p. 351-352.

${ }^{79}$ AUGÉ, M. Liturgia - história, celebração, teologia e espiritualidade. São Paulo: Ave Maria, 1996, p. 352.

${ }^{80}$ Ibidem.
} 
espiritualidade, e a oração pessoal e a participação litúrgica fluam como um mesmo movimento do crente para Deus Pai, por Jesus Cristo, no Espírito. [...] recorda-se mais uma vez a necessidade da assistência do Espírito santo, 'mistagogo' interior da oração cristã $[\ldots]^{81}$

Martín toca em um ponto teológico fundamental na compreensão da Espiritualidade Litúrgica, ou seja, a teologia do auxilio do Espírito Santo, que ora em nós. Em $R m$ 8, 26-27, afirma Paulo:

Assim também o Espírito socorre a nossa fraqueza. Pois não sabemos o que pedir como convém: mas o próprio Espírito intercede por nós com gemidos inefáveis, e aquele que perscruta os corações sabe qual o desejo do Espírito, pois é segundo Deus que ele intercede pelos santos.

Discorrendo acerca da fraqueza humana, não sabemos orar como convém, por isso, o Espírito Santo que em nós habita nos auxilia em nossas orações, fazendo-nos pedir o que convém. A oração eficaz é aquela que tem o Espírito como seu autor. Sem o auxílio do Espírito jamais oraríamos com discernimento. Esta teologia do 'auxilio oracional pneumático’ é comum também na teologia protestante. Calvino (15091564), enfatiza: "Não podemos nem sequer abrir a boca diante de Deus sem grande perigo para nós, a não ser que o Espírito Santo nos guie à forma devida de orar". ${ }^{82}$

O Espírito ora conosco e por nós, portanto, é nosso mistagogo interior que vai pedagogicamente conduzindo-nos ao Mistério que é Cristo, como assevera Triacca, que é "[...] por obra do Espírito Santo que toda ação litúrgica manifesta e realiza a presença de Cristo e que a 'memória' do 'mistério salvífico' não se limita a ser simplesmente uma piedosa recordação [...]", ${ }^{83}$ mas antes, pela ação pneumática na Liturgia que esta anamnese é histórico-salvífica.

Em suma, a Litrugia é Escola de Oração e o Espírito Santo o mestre. Martín afirma em uma frase lacônica, porém, que bem expressa o que neste item abordamos: "A Liturgia não somente é lugar por antono-

${ }^{81}$ MARTÍN, J. L. A Liturgia da Igreja. Teologia, história, espiritualidade e pastoral. São Paulo: Paulinas, 2006, p. 488.

${ }^{82}$ CALVINO, J. Institución, III.20.34.

83 TRIACCA. A. Espirito Santo. In: SARTORE, D; TRIACCA, A. M. Dicionário de Liturgia. São Paulo: Paulinas, 1993, p. 359 (verbete: Espirito Santo). 
másia da oaração cristã, mas também seu modelo e sua referência necessária" ${ }^{44}$

\section{Considerações finais}

A tarefa posta de discursar sobre o Mistério de Deus à teologia é confrontada pela hodierna mentalidade. O teólogo encontra-se muito bem representado no conhecido relato de Söre Kierkegaard sobre o palhaço e a aldeia em chamas, assertiva esta citada por Josef Ratzinger em sua obra Introdução ao Cristianismo. O conto kierkegaardiano relata a história de um circo que pega fogo na Dinamarca. O palhaço já caracterizado para sua apresentação: peruca, maquiagem, roupas coloridas e hilárias, vai à aldeia vizinha alertar a população acerca do perigo das chamas se espalharem do circo até a aldeia. Ao chegar à aldeia, o palhaço, desesperado, grita, corre e pede socorro - o circo está em chamas!, na esperança dos aldeões auxiliarem na tentativa de apagar o fogo. Contudo a população ri enlouquecidamente da atuação do palhaço e dizem estarem quase se convencendo do real incêndio do circo se não fosse sua excelente representação. Tomando os gritos do palhaço como um formidável truque de publicidade, a população aplaude e ri. Por mais que o palhaço tentasse esclarecer, mais hilários ficavam os aldeões, tornando tardia a tentativa de auxílio. Assim, circo e aldeia depressa ficam destruídos pelas chamas. Ratzinger retoma o conto de Kierkegaard dizendo que é símile da situação do teólogo hodierno, em que se vê a figura do teólogo na do palhaço incapaz de transmitir aos homens a sua mensagem.

Este cenário kierkegaardiano e ratzngeriano é corrborado pela frase de Karl Rahner que introduzimos nosso trabalho. Rahner afirma que o cristão do século XXI ou será místico ou não será cristão. Mais do que nunca urge a tarefa posta aos cristãos de testemunharem sua experiência com o Mistério que é Jesus Cristo. O homem pós-moderno necessita de experiência, afetividade e individuação. Só com discursos teológicos e racionais não levaremos este homem hodireno ao discipulado de Jesus Cristo, contudo, o testemunho de uma experiência com o Mistério arrasta. Assim, urge na Igreja uma Espiritualidade mistagógica em que o Espírito Santo seja nosso mestre e a própria comunidadde eclesial pela Liturgia seja uma Schola Oratio.

${ }^{84}$ MARTÍN, J. L. A Liturgia da Igreja. Teologia, história, espiritualidade e pastoral. São Paulo: Paulinas, 2006, p. 488. 


\section{Referências}

AGOSTINHO. Sermão 85,1.

AUGÉ, M. Liturgia - história, celebração, teologia e espiritualidade. São Paulo: Ave Maria, 1996.

BEAUDUIN, L. Histoire du mouvement liturgique. Esquisse historique dépuis le début du XIX jusq`au pontifical de Pie X. In: Lex Orandi 3, Paris, 1945.

BALTHASAR, Hans Urs von. El misterio pascual. In: Mysterium Salutis. Fundamentos de la dogmátima como historia de la salvación 3/1. Madrid, 1969.

BECKHÄUSER, Alberto. O Sentido da Liturgia das Horas. Petrópolis: Vozes, 1996.

BERGAMINI, A. Cristo, festa da Igreja - o Ano Litúrgico. São Paulo: Paulinas, 1994.

BÍBLIA DE JERUSALÉM: antigo e novo testamento. São Paulo: Paulus, 2002.

CALVINO, J. Institución, III.20.34.

CELAM. Manual de Liturgia IV: a celebração do mistério Pascal. São Paulo: Paulus, 2007.

DELARUELLE, E. La Gaule chrétienne à 1' époque franque. In: Revue d'Histoire de l'Eglise de France 38, 1952.

FLORES, J. J. Introdução à Teologia Litúrgica. São Paulo: Paulinas, 2006.

GILSON, E. Études de philosophie médiévale. Université de Strasbourg, 1921.

ISNARD, C. Dom Martinho: vida e obra do grande abade do Mosteiro de S. Bento do Rio de Janeiro. Rio de Janeiro: Lumen Christi, 1999.

IGLÉSIAS, Paula. Uma Lectio Divina: na Bíblia, na História de Israel, na Liturgia. Juiz de Fora: Edições Subiaco, 2010.

IRABURU, J. M. Espiritualidad católica. Madrid: [?], 1982.

LE BRAS, G. Les pénitentiels irlandais. In: La vie quotidienne dans l'Empire caroligien. Paris, 1973.

LECIONÁRIO. São Paulo: Paulinas, 1994.

LOYOLA, I. Gli scritti. Turin: Utet, 1977.

L'OSSERVATORE ROMANO. n. 24, 14 de Agosto de 1992, p. 22.

LUPI, J. E. P. Humanismo medieval (org. com Arno Dal Ri Júnior). Unijuí, 2005.

MARSILI, S. Mistero di Cristo e liturgia nello Spirito. Cidade do Vaticano: Libreria Editrice Vaticana, 1986.

MARTÍN, J. L. A Liturgia da Igreja. Teologia, história, espiritualidade e pastoral. São Paulo: Paulinas, 2006.

MAZZA, E. La mistagogia. Uma teologia della liturgia in epoca patrística. Roma: Edizione Liturgiche, 1988. 
PÁDUA. L. P. Mística, mística crstã e experiência de Deus. In: Atualidade Teológica, 15, 2003. p. 344-373.

PELlEGRINO, Michele. Dicionário Patrístico e de Antiguidades Cristãs. Petrópolis: Vozes, 2002.

POULAIN, A. Des grâces d'oraison: traité de théologie mystique. Paris: Beauchesne, 1931.

RATZINGER, Joseph. Introdução ao cristianismo. São Paulo: Herder, 1970.

SÃO JOÃO DA CRUZ. Subida do Monte Carmelo. In: Obras completas. Petrópolis: Vozes, [?].

SARTORE, D; TRIACCA, A. M. Dicionário de Liturgia. São Paulo: Paulinas, 1993.

SILVA, J. A. O Movimento litúrgico no Brasil. Estudo histórico. Petrópolis: Vozes, 1983.

SUDBRACK, J. Mística: a busca do sentido e a experiência do absoluto. São Paulo: Loyola, 2007.

TOLDO, R. L`anno litúrgico come itinerário permanente dela comunità Cristiana. In: Rivista Liturgica, ano 1988, n. 4, p. 531-553.

TRIACCA. A. Espirito Santo. In: SARTORE, D; TRIACCA, A. M. Dicionário de Liturgia. São Paulo: Paulinas, 1993.

VAGAGGINI, Cipriano. Il senso teologico della liturgia. 5. ed. Roma, 1968.

VAUCHEZ, A. A espiritualidade na Idade Mádia Ocidental - Séculos VIII a XIII. Rio de Janeiro: Jorge Zahar Editor, 1995.

VELASCO, M. El fenómeno místico. Estudio comparado. Madrid: Editorial Trotta, 2003.

Recebido: 07/12/2012

Avaliado: 15/08/2014 